\title{
Perspectives of plantation forests in the sustainable forest development of China
}

\author{
Taimoor Hassan Farooq ${ }^{(1-2)}$, \\ Awais Shakoor ${ }^{(3)}$, \\ Xiaohong $\mathrm{Wu}^{(1-2)}$, \\ Yong $\mathrm{Li}^{(1-2)}$, \\ Muhammad Haroon U Rashid ${ }^{(4)}$, \\ Xiang Zhang ${ }^{(1-2)}$, \\ Matoor Mohsin Gilani ${ }^{(4)}$, \\ Uttam Kumar ${ }^{(5)}$, \\ Xiaoyong Chen ${ }^{(2-6)}$, \\ Wende Yan ${ }^{(1-2)}$
}

\begin{abstract}
Modern forestry is gradually moving towards man-made forests on a large scale. Plantations with advanced forestry system have been introduced with the goal of sustainable forestry development and to enhance social, ecological, and economic benefits. Forest plantations with native and exotic species have been established in China and worldwide with shorter rotation cycles than natural forests. In this paper, we discuss the role and perspectives of plantation forests in the Chinese sustainable forest development, the evolution of various plantation programs, the ecological effects of plantations, and the measures to improve plantation forestry. The Chinese government has given substantial importance to nurturing plantation forest resources through various large scale afforestation programs. In 2019 , the total area covered by plantations in China reached 79.54 million ha, with a stock volume of 3.39 billion $\mathrm{m}^{3}\left(59.30 \mathrm{~m}^{3}\right.$ per ha); coniferous forests (26.11 million ha, $32.83 \%)$ and broad-leaved forests (26.45 million ha, $33.25 \%)$ are the dominant types. Plantations have been primarily distributed in the central and southern parts of the country. Plantations with fast-growing and high-yielding tree species facilitated Chinese afforestation activities and improved the administration of forest production, which ef fectively boosted the forest industry. Plantation forest resources offer many potential productive, economic, and social advantages, though they are also associated with a loss of biodiversity and climate change makes them likely susceptible to disease and insect attack. Appropriate forest management practices during planning, execution, and maintenance of plantations can contribute to the conservation, promotion, and restoration of biodiversity, with the final aim of attaining a balance between having forest plantations and natural forests.
\end{abstract}

Keywords: Chinese Fir, Poplar, Eucalyptus, National Forest Inventories of China, Ecological Implications

\section{Introduction}

Cultivating plantations is an effective way to preserve and protect natural forest resources. Artificially reconstructed forests play a critical role in improving the environment, promoting industrial restructuring, and alleviating timber supply pressure (Aronson \& Alexander 2013, Wang et al. 2017). The rise of the $20^{\text {th }}$ century brought rapid development in the industrial world; thus, the race of vast accumulation of wealth negatively impacted the world's forests, and forest areas sharply decreased in many countries/regions (Trumbore et al. 2015). Transport infrastructure for mining/ energy, road construction, industrial logging, agricultural expansion, and wildfires were significant drivers of forest coverage loss (Scullion et al. 2019). Since 1990, an estimated 420 million ha of global forest coverage has been lost due to deforestation. In most recent times (2015-2020), the annual deforestation rate decreased from 12 million (2010-2015) to 10 million (FAO 2020), mainly by increasing plantation forests. There is a significant concern whether natural forests can cope with the demand for sustainable development of human society (Oliet \& Jacobs 2012).
China is well-known for its varied climatic and geomorphological conditions, and for its vast land territory, which provides an inclusive background for vegetation establishment and tree species growth. China's forest land has been cleared over the decades by agricultural expansion. At the founding of Peoples Republic of China in 1949 , the forest cover was merely $9 \%$ of the total land area. Even further deforestation happened in the 1970s (Yu et al. 2011, Miao et al. 2013). Just three decades before, China was one of the countries with the lowest forest area per capita worldwide. Natural forests and plantations were deficient and unevenly distributed with low quality (Lü et al. 2011, Xu et al. 2012).

The unprecedented economic development of China and the fast population growth have led to a dramatic upsurge of wood consumption in many regions, resulting in several well-known ecological disasters such as soil erosion and flooding (Yin et al. 2005). This caused unmeasurable environmental damage with long-term social and economic impacts (Aronson \& Alexander 2013). However, emergency measures were taken to overcome this, and today China has the most extensive plantation 
Tab. 1 - Main structural and silvicultural differences between natural forests and plantations in China (Avtar et al. 2014)

\begin{tabular}{ll}
\hline Natural forests & Plantations \\
\hline Multi-layered & Single-layered \\
\hline Complex structure & Simple structure \\
\hline Multispecies & Usually single species (monoculture) \\
\hline Flora and fauna richness & Poorer flora and fauna \\
\hline High biomass density & Less biomass density \\
\hline Sequester more carbon & Sequester less carbon \\
\hline Continues plant growth & Initial fast growth \\
\hline Time-consuming forest inventory & Fast and easy forest inventory \\
\hline Labor intensive forest management & Cost-efficient forest management \\
\hline High uncertainties in inventory data & Inventory data has fewer uncertainties \\
\hline Natural rotation cycle & Generally short rotation \\
\hline No fixed but continued return & Economic return after a fixed time \\
\hline Higher ecological benefits & Higher timber yield \\
\hline
\end{tabular}

area worldwide (Zeng et al. 2015).

With the rapid increase of the economy, the demand for timber increased, affecting the natural forests; therefore, many conservation programs were launched in China to protect natural forests. To ensure a sustainable forest development, various measures have been taken by the Chinese government on an emergency basis. Multiple programs were introduced such as the

"China Natural Forest Protection Program" (Ren et al. 2013, Zeng et al. 2015), "China Fast-Growing and High-Yield Plantation Program", "Integrated Intensive Forest Management (IIFM) Project", "Research on China's Plantation Woods" etc. (Zhang et al. 2010, 2016). Afforestation of scarsely forested lands was implemented, and legal harvesting in natural forests was significantly reduced. High yielding and fast-

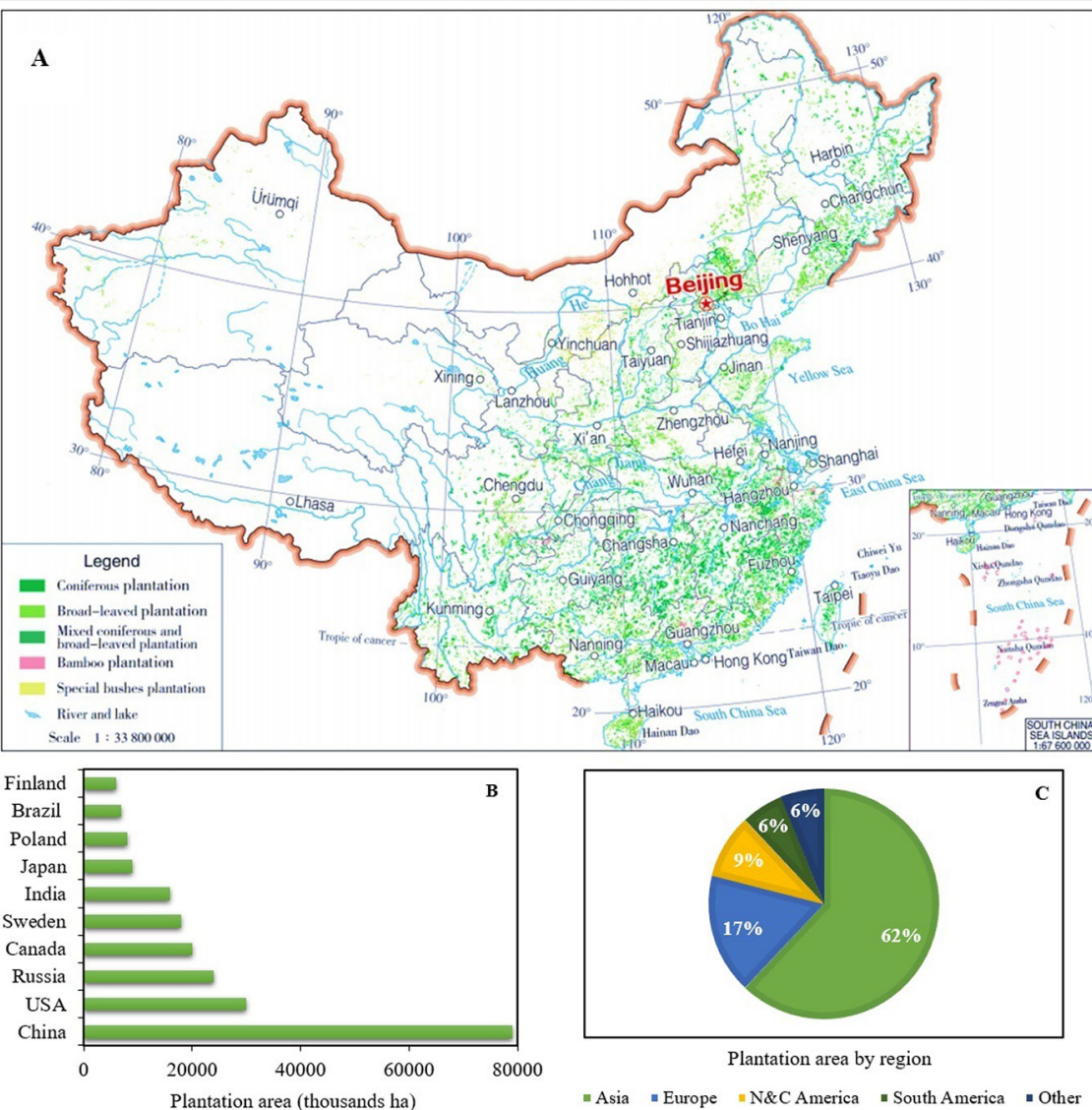

Fig. 1 - (A) Distribution of area under plantations in China (SFA 2019); (B) major countries in terms of tree planting area (in thousands ha); (C) plantation area (\%) by region. growing timber species were introduced to cope with the ever-increasing timber demand. Relevant sectors and industries have been encouraged and promoted to gain substantial benefit by steadily enhancing the technical and administrative levels. Besides playing its role in the national economy and social development by improving timber and non-timber forest goods, plantations also play a vital part in enhancing the ecological environment in many areas.

Although natural forests provide higher environmental services than plantations (Yamagawa et al. 2010, Xu et al. 2012), the latter also play a vital role by provisioning clean air and water protection. Plantation forests can provide most services such as woody and non-woody products, biodiversity, aesthetics, carbon sequestration, climate control, and soil erosion control (Sasaki \& Yoshimoto 2010, Ruiz-Jaen \& Potvin 2011, Farooq et al. 2019a, 2019b, 2019c). Plantations grow much faster than the natural forests, having specific value in terms of timber supply, fast forest spread, and ecosystem conservation (Chinnaraj \& Malimuthu 2011, Farooq et al. 2018, 2019a, 2019b). Hence, plantations have become a crucial part of China's afforestation efforts to tackle climate change and air pollution (Zeng et al. 2015). Tab. 1 reports the main structural and silvicultural differences between natural forests and plantations in China. The interest in plantations was relatively scarce in the past; however, the concept and related practices are not new (Paquette \& Messier 2010, Gerber 2011).

In this paper, the Chinese approach to developing plantation forests and its progress over the years is reviewed, including their current status and perspectives. Moreover, we discuss the ecological implications and measures for their improvement.

\section{Materials and methods}

This study was carried out based on the published data (1970-2020) collected from Clarivate Web of Science ${ }^{\circledast}$ (http://apps.web ofknowledge.com/) and the China Knowledge Resource Integrated Database (http://www.cnki.net/), using the terms "plantation forest", "sustainable forestry", "forest sector", "ecological implication", and "ecological impacts" as keywords. Moreover, some common grey literature such as reports, evaluations, and government documents were also used to fulfill minor information gaps. According to the relevance of publication title and abstract, we excluded studies that did not precisely meet our objectives. Various publications and documents reporting similar data were excluded to avoid duplication. Overall, data from 99 studies were used, including journal and non-journal resources.

\section{Status of plantations and evolution of reforestation programs}

The Chinese government has given sub- 
stantial importance to nurturing forest plantations, and many large scale afforestation and regreening programs were carried out. Currently, China has the most extensive plantations with the highest afforestation rate worldwide, mostly using fast-growing species (Yang et al. 2010). In the last three decades, China has planted about 6.6 million ha of forest area every year due to the national forest protection programs, with an average increase of $1.1 \%$ per year. Since the government first introduced a nationwide tree-planting program in 1981, volunteers have planted over 45 billion trees.

Currently, the area under plantation in China ranks first in the world (SFA 2019). The total area of plantations reached 79.54 million ha in 2019, with a stock volume of 3388 billion $\mathrm{m}^{3}$ ( $59.30 \mathrm{~m}^{3}$ per ha). Coniferous forests (26.11 million ha, 32.83\%) and broad-leaved forests (26.45 million ha, $33.25 \%$ ) are the dominant types (Fig. 1). The government is currently looking to implement forest policy measures to increase the spread, quantity and quality of forests with the aim of increasing forest cover to $23 \%$ by 2020 , and to $30 \%$ by 2050 .

Plantation resources have been primarily distributed in the central and southern parts of the country. Provinces including Guangdong, Guangxi, Hunan, Inner Mongolia, Sichuan, Yunnan have a significant cover of plantations (Farooq et al. 2019a), accounting for $43.50 \%$ of the total national plantation area (SFA 2019). The area of the young plantations (1-10 years), middle-aged plantations (10-20 years), near-mature plantations (around 25 years), mature plantation (25-35 years), and over mature plantations is 23.26, 16.97, 8.09, 6.59 and 2.23 million ha, respectively; the stock volumes are $585,1115,723,720$, and 245 million $\mathrm{m}^{3}$, respectively (Fig. 2).

According to China's $9^{\text {th }}$ forest inventory report for the period 2014-2018 (Fig. 3), the standing volume stock of plantations accounts for $19.24 \%$ of the entire volume stock in the country (Zeng et al. 2015). Due to high domestic demand, plantation area is expected to increase rapidly. Out of the total plantation area, $36.26 \%$ has been planted with cash trees crops, $3.1 \%$ with bamboo plantations, and the remaining $60.64 \%$ with other species. Plantations for timber production cover the most significant area, accounting for $70 \%$ of the total plantations and including protective, fuelwood, and special-use plantations (SFA 2014). Several dominant softwood and hardwood species were introduced during reforestation programs in China (Bao \& Jiang 1998). Plantations have been established using more than 2500 different tree species, the most used being Chinese fir (Cunninghamia lanceolata), Poplar (Populus spp.), and Eucalyptus spp., which account for $50 \%$ of all planted species (SFA 2019 Fig. 4). A list of the main tree species used in Chinese plantations are reported in Tab. 2. The total plantation area of the ten soft-

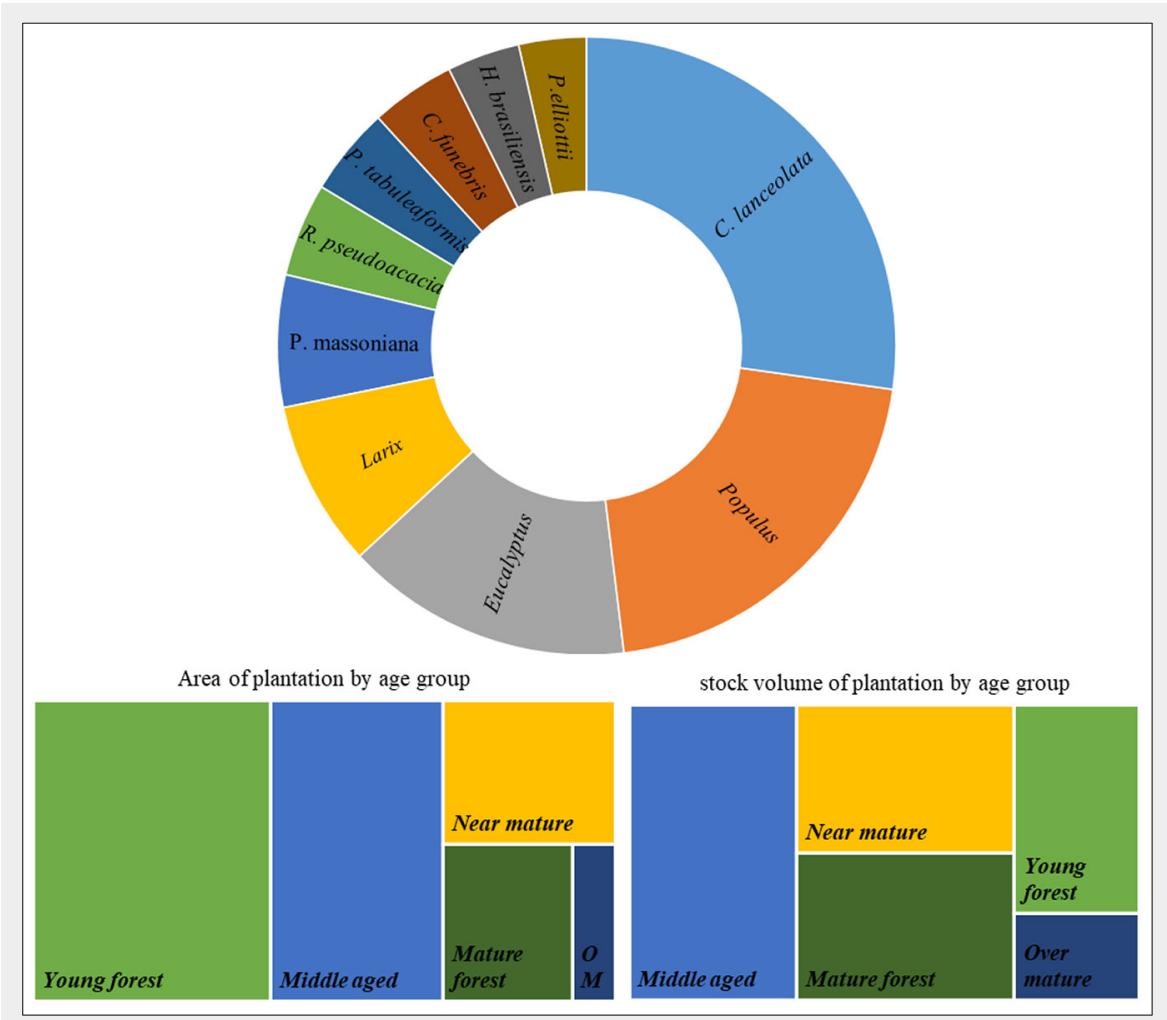

Fig. 2 - (above) Partition of the total plantation area in China by dominant species; (below) partition of the total plantation area (left) and stock volume (right) by different age groups (Zeng et al. 2015).
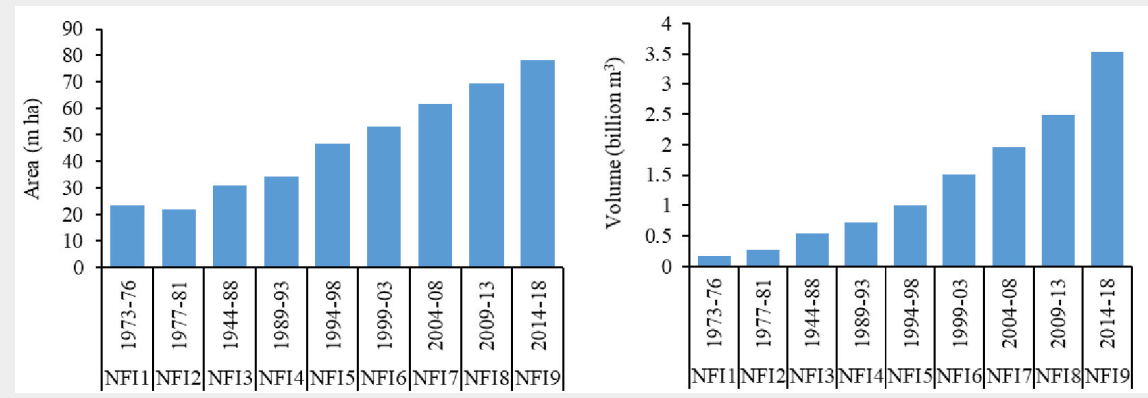

Fig. 3 - The increase in surface area and growing stock volume of plantations forests in China from nine national forest inventories (NFIs). Source: ninth national forest inventory (2019).

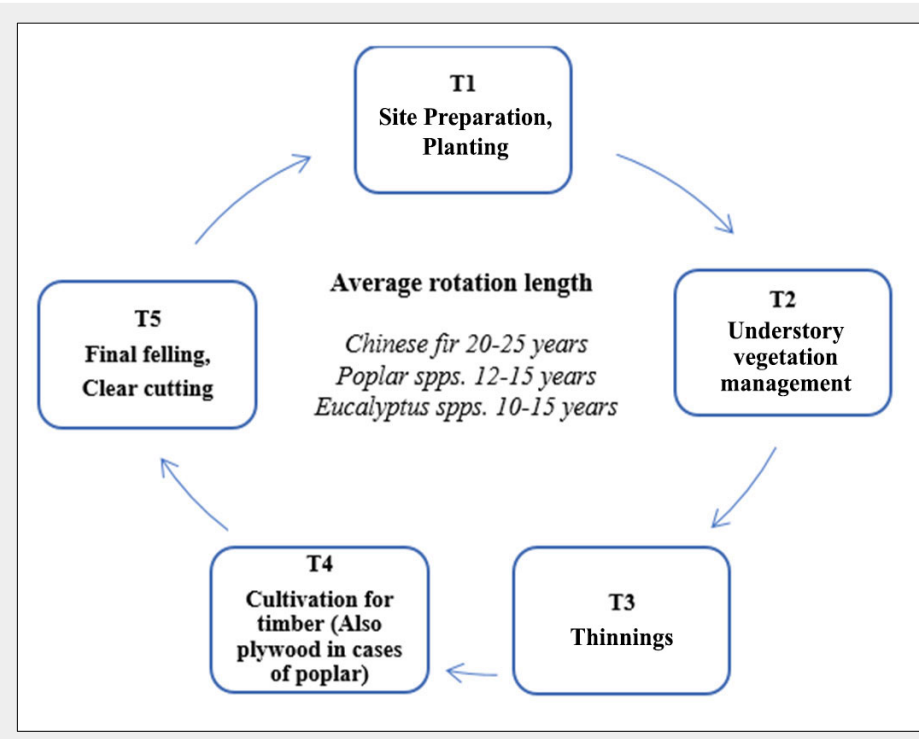

Fig. 4 - The silvicultural cycle of the three dominant species in Chinese (Chinese fir, Poplar, and Eucalyptus spp.). plantations 
wood species amounts to $63.65 \%$ of the national total, and their stock volume accounts for $68.47 \%$. Plantation stands in the uplands of China also protect the lowland river valleys from the severity of droughts and floods by preventing erosion, and making the intensive irrigated agriculture system conceivable (Bao \& Jiang 1994, Bao \& Lu 1998). For rural households, these stands are the source of $40 \%$ of the fuel, making China one of the world's most forest-dependent countries.

In the last two decades, many afforestation projects have been started to establish high yield and fast growing stands (Fig. 5). These programs include: (1) CCPF (covering 25 provinces); (2) NFPP (covering 17 provinces); (3) WCNRDP (including all the country); (4) SDP-YR (covering 31 provinces); (5) SDP-TN (including 13 provinces); (6) SCP Beijing and Tianjin; (7) PICLD (covering eight provinces); (8) WCRP; (9) FIBRP (covering 18 provinces). Over the period 20102050, 13 million ha of new plantations are planned to be established by undertaking large-scale afforestation of barren and arid lands in western China (SFA 2009, Xu et al. 2012, Zeng et al. 2015, Shi et al. 2016). To es- tablish the plantations, China is mostly following the unified Brazilian and Chilean model which developed monocultural stands to facilitate higher timber quality and production (Zhang et al. 2015). The Chinese government provided loans and subsidizes for forest projects to expand the area under plantations. Over $40 \%$ of these loans were used to establish high-yielding and fast-growing timber species, and these species facilitated Chinese afforestation technology and turned into a productive force (Yang et al. 2010, Farooq et al. 2019a). Establishing plantations also improved the administration of forest production, which effectively boosted the forest industry (Zhang et al. 2010, 2015)

The contribution of these plantations in terms of pulp and paper production will depend on the suitability of ecological conditions at plantation sites and whether these plantations will reach their full potential without being damaged from any disease or insect attack (Barr \& Cossalter 2004). Up to date, some plantations are claimed to be inefficient in enhancing ecological and economic benefits. Overall, these plantation programs have been relatively suc- cessful in significantly reducing soil erosion and flooding, in particular the multi-species stands around the upper reaches of major rivers (Zhang et al. 2010, Xu 2011). Moreover, logging was banned entirely in environmentally sensitive areas (Zhang et al. 2015).

\section{Ecological effects of plantations}

Along with many positive impacts associated with the expansion of timber plantations (such as the decreasing pressure on and the reduced degradation of natural forests - Pirard et al. 2016), plantations also have some direct adverse ecological effects. For example, even-aged and monoculture plantations over the successive rotations can result in loss of soil nutrients and suitable habitats for taxa living in natural forests (Ma et al. 2000, 2007, Lin et al. 2001, Erskine et al. 2006, Larjavaara 2008, Chen et al. 2009, Hartmann et al. 2010, Xu 2011, Liao et al. 2012, Zhou et al. 2015). Also, these forest stands may alter soil physiochemical, biological properties, and affect water resources (Scott 2005, Stenert et al. 2012). In a study, Yang et al. (1998) stated that, the soil nutrient, microbes, and bio-

Tab. 2 - Dominant softwood and hardwood species in the plantation forests of China.

\begin{tabular}{|c|c|c|c|c|c|c|c|c|}
\hline Group & No & Species & Common Name & Family & Origin & $\begin{array}{l}\text { Planting } \\
\text { material }\end{array}$ & $\begin{array}{c}\text { Typical } \\
\text { Height (m) }\end{array}$ & Area of Cultivation \\
\hline \multirow{10}{*}{ 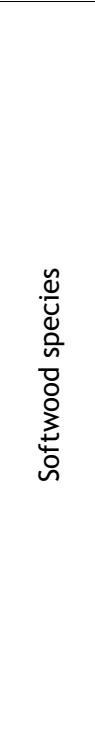 } & 1 & $\begin{array}{l}\text { Cunninghamia } \\
\text { lanceolata }\end{array}$ & Chinese fir & Cupressaceae & Native & Seed/Seedlings & $15-30$ & $\begin{array}{l}\text { Predominantly in Southern } \\
\text { China }\end{array}$ \\
\hline & 2 & Pinus massoniana & Masson pine & Pinaceae & Native & Seed/Seedlings & $25-40$ & $\begin{array}{l}\text { Predominantly in Southern } \\
\text { China }\end{array}$ \\
\hline & 3 & Larix spp. & Dahurian larch & Pinaceae & Exotic & Seed/Seedlings & $20-45$ & $\begin{array}{l}\text { Liaoning, Heilongjiang, } \\
\text { Sichuan, Henan, and Hubei }\end{array}$ \\
\hline & 4 & Pinus tabuleaformis & $\begin{array}{l}\text { Manchurian red } \\
\text { pine }\end{array}$ & Pinaceae & Native & Seed/Seedlings & $20-30$ & $\begin{array}{l}\text { Most parts of China, } \\
\text { except for Liaoning }\end{array}$ \\
\hline & 5 & Cupressus funebris & $\begin{array}{l}\text { weeping } \\
\text { cypress }\end{array}$ & Cupressaceae & Native & Seed/Seedlings & $20-35$ & $\begin{array}{l}\text { Southwestern and central } \\
\text { China }\end{array}$ \\
\hline & 6 & Pinus elliottii & Slash pine & Pinaceae & Exotic & Seed/Seedlings & $18-30$ & $\begin{array}{l}\text { Primarily in Pearl and } \\
\text { Yangtze river valleys }\end{array}$ \\
\hline & 7 & Pinus yunnansis & Yunnan pine & Pinaceae & Native & Seed/Seedlings & $20-40$ & $\begin{array}{l}\text { Yunnan, Sichuan, Guizhou, } \\
\text { and Guangxi }\end{array}$ \\
\hline & 8 & Pinus taeda & Loblolly pine & Pinaceae & Exotic & Seed/Seedlings & $30-35$ & $\begin{array}{l}\text { Primarily in Pearl and } \\
\text { Yangtze river valleys }\end{array}$ \\
\hline & 9 & $\begin{array}{l}\text { Pinus sylvestris } \\
\text { var. Mongolica }\end{array}$ & $\begin{array}{l}\text { Mongolian } \\
\text { Scotch pine }\end{array}$ & Pinaceae & Exotic & Seed/Seedlings & $\leq 35$ & Northwestern China \\
\hline & 10 & Pinus koraiensis & Korean pine & Pinaceae & Native & Seed/Seedlings & $15-30$ & Northeastern China \\
\hline \multirow{6}{*}{ 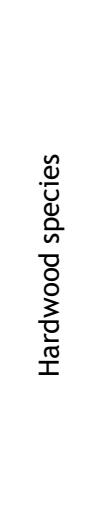 } & 1 & Populus spp. & Poplar & Salicaceae & Exotic & $\begin{array}{l}\text { Seed/Seedlings/ } \\
\text { Cuttings }\end{array}$ & $15-50$ & All over the China \\
\hline & 2 & Eucalyptus spp. & Eucalyptus & Myrtaceae & Exotic & Seed/Seedlings & $10-60$ & $\begin{array}{l}\text { Guangdong, Hainan, } \\
\text { Yunnan, Fujian, and } \\
\text { Guangxi }\end{array}$ \\
\hline & 3 & $\begin{array}{l}\text { Robinia } \\
\text { pseudoacacia }\end{array}$ & Locust & Fabaceae & Exotic & Seed/Seedlings & $12-18$ & $\begin{array}{l}\text { Cultivated in all of China } \\
\text { except Hainan and Xizang }\end{array}$ \\
\hline & 5 & Hevea brasiliensis & $\begin{array}{l}\text { Pará rubber } \\
\text { tree }\end{array}$ & Euphorbiaceae & Exotic & Seed/Seedlings & $\leq 43$ & $\begin{array}{l}\text { Fujian, Guangdong, } \\
\text { Guangxi, Hainan, Taiwan } \\
\text { and Yunnan }\end{array}$ \\
\hline & 6 & Paulownia spp. & Paulownia & Paulowniaceae & Native & Seed/Seedlings & $\leq 35$ & $\begin{array}{l}\text { All of China. predominant- } \\
\text { ly in Southern China }\end{array}$ \\
\hline & 7 & Betula spp. & Birch & Betulaceae & Native & Seed/Seedlings & $\leq 20$ & $\begin{array}{l}\text { Predominantly } \\
\text { Northeastern China }\end{array}$ \\
\hline
\end{tabular}


chemical activities of total and rhizosphere soil in a plantation forest were largely affected compared to the natural forest of Castanopsis kauakamii in Xinkou, Sanming city, Fujian province, China. Their results showed that the soil nutrients variability and enzymatic activity, the abundance of soil microbiota, biological activities, and soil physiological monoids in the rhizospheric and total soil profile of Castanopsis plantation were lower than those of the natural stands. Moreover, in plantation stands, the depletion of soil available nutrients was observed (Yang et al. 1998).

Intensive management such as clear-cutting and successive rotations ( $M a$ et al. 2000, Zhou et al. 2015, 2016), results in low structural complexity of plantations, which raises concerns about the reduction of local diversity, water table level and soil nutrient stocks. The majority of plantations harvested at economic optimum rather than at biological maturity can develop extreme nutrient deficiencies, affecting nutrient cycling and long-term productivity (Liu et al. 2018). For example, Eucalyptus is one of the main species planted in southern China with successive rotations (monoculture), being extremely beneficial both socially and economically. Eucalyptus absorbs nutrients and water quickly during its growth compared to other plants, resulting in a quick reduction of nutrients in the soil and causing water inequity (Bao \& Jiang 1994). On the contrary, the establishment of Eucalyptus plantations does have positive impacts on reducing soil erosion due to the rainfall extreme events (Zhao 1988, Zhou et al. 2002). Besides, over-fertilization reduces understory vegetation and groundcover diversity (Evans 1976, Wang et al. 2010, Liu et al. 2018). Furthermore, the introduction of exotic species and single-layered plantations can make these stands susceptible to insects and diseases (Hu et al. 2006, Larjavaara 2008, You et al. 2015).

Plantation forests can also be the cause of local extinction of various species (Pereira et al. 2012) by homogenizing the stand pattern and structure (Araujo et al. 2010, Rundel et al. 2014), thus favoring invasive species (Martin et al. 2012). On the opposite, some researches showed that plantations provide ecosystem services and promote the conservation of biodiversity similarly to natural forests (Carnus et al. 2006, Brockerhoff et al. 2013), by maintaining the native flora (Abreu et al. 2011) and fauna (Carrara et al. 2010). Focusing on the wood provision, plantations actively contribute to regulating the social ecosystem services, especially through carbon sequestration and recreation. The adverse ecological influences of plantations have been primarily attributed to improper management. Fast-growing species absorb a large amount of nutrients from the soil to maintain rapid growth, however, trees also produce nutrients through photosynthesis. Much of the nutrients absorbed from soil

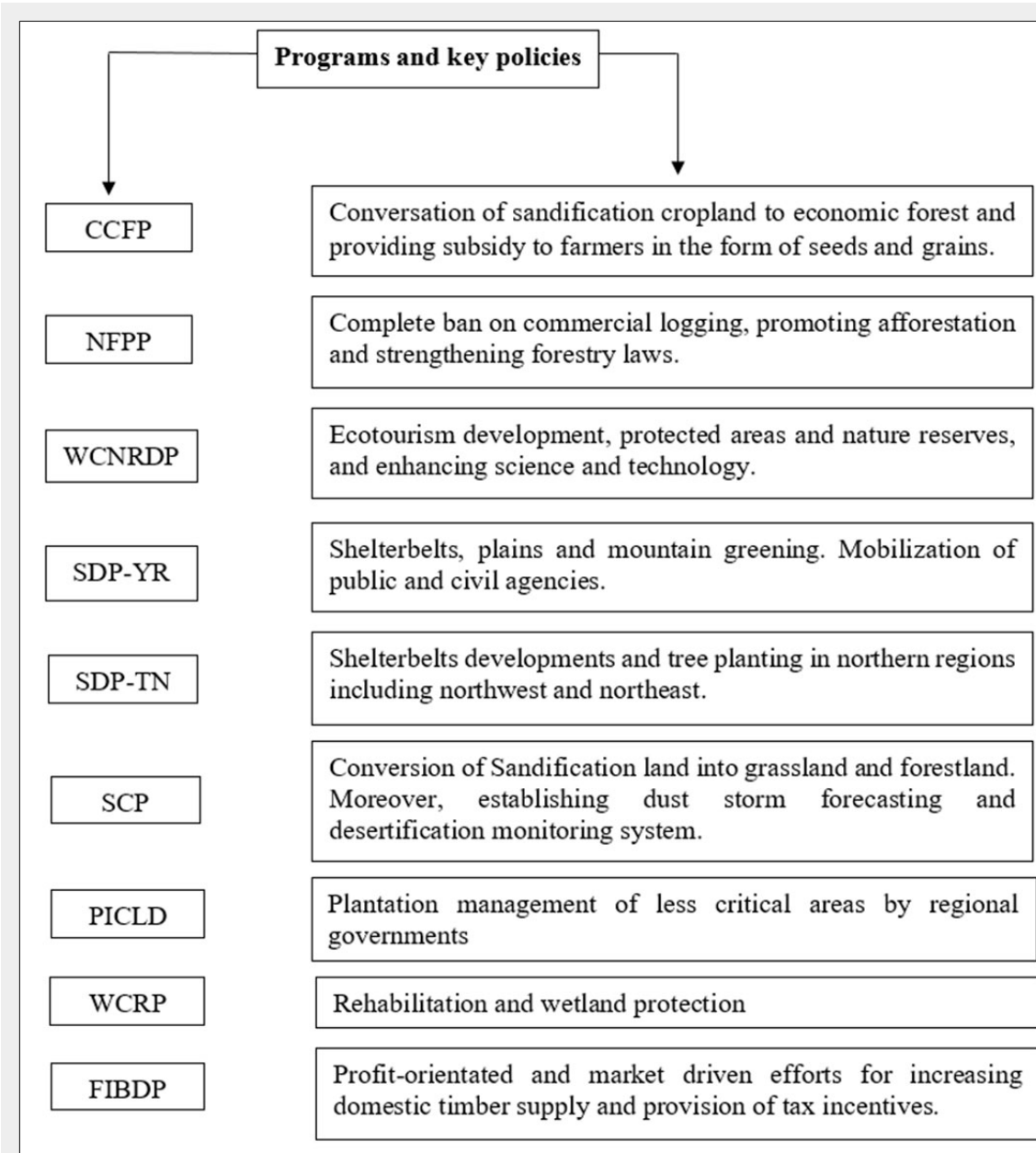

Fig. 5 - Priority plantations forestry programs of China for various regions in the last two decades and critical policy measures associated with them (for abbreviations, see the main text).

or produced in leaves return to the soil through dead leaves and branches. Therefore, a steady nutritional balance of soil can be kept under correct management, for example by avoiding clear-cutting practice, complete plowing and burning, and residue removal. These practices are often blamed for site degradation, which results in low growth and productivity (Bhardwaj et al. 2014, Dias et al. 2015, Zhou et al. 2016, Farooq et al. 2019a).

When plantations replace other productive land uses, such as agriculture, they have usually considered the "lesser evil" among environmentalists (Brockerhoff et al. 2008). In support of this statement, Stephens \& Wagner (2007) showed that when prior land use was considered in the comparisons, plantations host a greater diversity than the former land use. However, substantial work is required to test whether plantations meet a broader spectrum of sustainability criteria. If, in the future, harvesting in the natural forests has to be reduced and replaced by plantations, extensive research is needed on multifunctional uses of plantation forests (Liu et al. 2008). Plantations offer important ecological benefits. Stands established keeping in view the soil type, topography, climatic conditions, and species, are recognized for their significance for sustainable production, improved soil and water quality, salinity mitigation, ecosystem services, and biodiversity benefits (Fox 2000, Zhou et al. 2002, Li et al. 2012); however, negative effects on environmental quality after the establishment of industrial plantations, especially on soil and water, is also reported (D'Amato et al. 2017). Due to the general perception of excessive water consumption, forest plantations and their possible impact on water resources have always been the subject of heated discussions. For example, Eucalyptus plantations have been often criticized for their high water consumption compared to other species, as it has been shown by past studies. Contrastingly, the results of other studies on water balance, water use efficiency, transpiration rate, and interception losses, proved that Eucalyptus does not consume more water per unit of produced biomass compared to any other forest species, and even exhibits superior water use efficiency (Zhao 1988, Zhou et al. 2002, Whitehead \& Beadle 2004, FAO 2011). Moreover, plantations reduce soil erosion, thus reducing run-off (Lima et al. 2012). Based on the this positive and encouraging evidence, plantations 
can also be recommended for soil and water conservation (Lindenmayer et al. 2006 Evans 2009).

\section{Measures to improve forest plantations}

(1) The development of high-yielding and fast-growing timber plantations should be based on experimental evidence. Site-specific experimental trials and a broader dissemination of optimized silvicultural techniques for various species can lead to extensive and quick improvements in stand productivity (Freer-Smith et al. 2019). The quality of plantations can be enhanced by gaining evidence from different scientific disciplines. For example, close attention should be paid to provenance and clone testing in small-scale forestry and to highperforming clones in terms of wood yield, matching the species to the site and considering the mortality of the species at each specific site (Freer-Smith et al. 2019). Field testing of nursery results should be implemented because sometimes the same provenances could be unsuccessful at different sites. Moreover, the lack of quality seeds combined with poor information on the adaptability of different species to different environmental conditions can also result in potential losses of yield and economic value.

(2) Due to short rotations and the small dimension of roundwood, timber obtained from plantations is often considered inferior compared to natural forest timber. Developing new and applying best-practiced wood engineering and processing techniques can improve the quality of plantation wood products. Extending the rotation cycle and/or optimizing planting density and tree spacing under natural conditions can improve stand structure over a long period (Lin et al. 2001, Li et al. 2017). However, it is still unclear which silvicultural methods are the most suitable to promote structural diversity in plantations.

(3) Globally, exotic species have been purposely introduced for economic or biological control purposes. A frequent outcome of these introductions is the extinction of the exotic species; however, when the exotic species adapt to the new environmental conditions, different effects are expected. Interactions between native and exotic species could result in a displacement and competitive exclusion of the native species. In some cases, native and exotic species may reach an equilibrium where resources are abundant, and the competitive interactions between them allow for local survival of both native and exotic species. Ehrenfeld (2003) stated that exotic plant species could enhance Nitrogen $(\mathrm{N})$ availability, alter $\mathrm{N}$ fixation rates, and produce litter with higher decomposition rates than co-occurring natives, increasing net primary production and biomass; however, the opposite patterns can also occur. In some cases, a given species has different responses at different sites, suggesting that environmental factors and soil type may determine the magnitude of ecosystem-level impacts. On the contrary, Corbin \& D'Antonio (2004) reported that exotic species could affect soil $\mathrm{N}$ stocks either by fixating atmospheric $\mathrm{N}$ or increasing $\mathrm{N}$ loss rates. In the latter case this could interfere with restoration efforts, though uncertainty still exists about the environmental restoration carried out by limiting or increasing exotic species (Abella et al. 2012).

(4) At the stand level, thinning and mixed planting may greatly enhance species and structural diversity of the stand, leading to size differentiation of trees and partly randomizing the initial regular pattern. Although both thinning and mixing promote structural diversity, thinning is expected to achieve the goal quicker because it directly manipulates the stand structure, thus accelerating the stand development ( $\mathrm{Li}$ et al. 2020).

(5) Monoculture, repeated planting, short rotations and clear-cutting can directly threaten plantation sustainability (Minghe \& Ritchie 1999, Widenfalk \& Weslien 2009, Wang et al. 2010, 2017). By contrast, the complex structure of the mixed forest may favor the productivity and the conservation of biodiversity (Erskine et al. 2006, Forrester et al. 2006, Zhang et al. 2012, Grossiord et al. 2013, Mayoral et al. 2017, Dong et al. 2018, Wu et al. 2018, Zemp et al. 2019). The above-mentioned studies infer that the deficiencies of monocultured plantations may be remedied by choosing complex and mixed cultivation (Mason et al. 2007). Establishing and maintaining mixed forests may promote indigenous forest species and preserve biodiversity at the landscape level. Moreover, clear-cutting and burying of residues should be avoided, while proper thinning and longer rotation cycles should be encouraged (Selvaraj et al. 2017, Farooq et al. 2019a).

Fruitful ecological restoration and progressive projects can attain both environmental and financial goals simultaneously (Tallis et al. 2008, Wunder et al. 2008, Wendland et al. 2010). In light of the aforementioned studies, we stress the importance of conducting an efficient forest management in plantations. Further, the concept of forest cultivation and management is dynamic, and should promote landscape heterogeneity, the maintenance of complexity, species diversity, and ecological functions. Forest cultivation needs to balance economic, environmental, and cultural principles, in order to achieve a sustainable production. Compliance with the aforementioned principles promotes the maintenance of ecosystem services and biodiversity for the future generations.

Additionally, various activities such as incentive policies, rightful ownership, clarity in structures, land availability, and social impacts of plantations require extensive monitoring. The establishment of plantations should be market-oriented and finan- cial resources should be mobilized through multi-channels. Furthermore, data inaccuracies about plantation area management must be corrected to provide an accurate picture for private and public policy setting.

\section{Conclusions}

With the implementation of programs for the protection of natural forests, China's wood supply sources are shifting from natural forests to plantations, the impact of which is mostly dependent on implementing sustainable strategies and management practices. However, extensive forest cultivation presents various challenges, such as diminished soil fertility, disease and pest attacks, decreased biodiversity, and reduced productivity. The sustainability of plantations will require diligent and watchful management of soils and stand structural diversity. Plantations should be established on the barren land, thus improving the ecological conditions of planting areas and increasing local biodiversity. This can be done only by understanding the ecological context of forest plantations in the broader spectrum. Although there is an increasing literature on plantations and their impacts, there is still a need for further studies on soil microbial and enzymatic activities that widen our understanding of the long-term effects of plantations. Because of the complexity of forest ecosystems in China, more species- and site-specific studies are required in order to provide the ecological knowledge needed to increase the sustainability of cultivated forests.

\section{Declaration of competing interest}

Authors declare no conflict of interest exists.

\section{Acknowledgments}

We thank the great help from two anonymous reviews. We also thank our friend Chris ljeoma for the grammar checking of the manuscript. The funding sources included the Postdoctoral research funding of Central South University of Forestry and Technology, Changsha, China (70702-4520 0003).

\section{References}

Abella SR, Craig DJ, Smith SD, Newton AC (2012). Identifying native vegetation for reducing exotic species during the restoration of desert ecosystems. Restoration Ecology 20 (6): 781787. - doi: 10.1111/j.1526-100X.2011.00848

Abreu RC, Assis GB, Frison S, Aguirre A, Durigan $G$ (2011). Can native vegetation recover after slash pine cultivation in the Brazilian Savanna? Forest Ecology and Management 262 (8): 14521459. - doi: 10.1016/j.foreco.2011.06.046

Araujo AS, Silva EF, Nunes LA, Carneiro RF (2010). The effect of converting tropical native savanna to Eucalyptus grandis forest on soil microbial biomass. Land Degradation and Development 21 (6): 540-545. - doi: 10.1002/ldr.993 Aronson J, Alexander S (2013). Ecosystem res 
toration is now a global priority: time to roll up our sleeves. Restoration Ecology 21 (3): 293296. - doi: 10.1111/rec.12011

Avtar R, Suzuki R, Sawada H (2014). Natural forest biomass estimation based on plantation information using PALSAR data. PLoS One 9 (1): e86121. - doi: 10.1371/journal.pone.0086121

Bao F, Jiang Z (1994). Studies on the properties of wood from fast-growing forest plantations. World Forestry Research, Ministry of Forestry, Beijing, China, vol. 7, pp. 340. [In Chinese]

Bao F, Jiang Z (1998). Wood properties of main tree species from plantation in China. Forestry Publishing House, Beijing, China, pp. 170. [In Chinese]

Bao FC, Lu JX (1998). The change in wood resources structure and the strategies for wood science research in China. Chinese Academy of Forestry, China Agricultural Science and Technology Press, Beijing, China, pp. 503-509. [In Chinese]

Barr C, Cossalter C (2004). China's development of a plantation-based wood pulp industry: government policies, financial incentives, and investment trends. The International Forestry Review 6 (3-4): 267-281. - doi: 10.1505/ifor.6.3.267. 59977

Bhardwaj D, Ansari MW, Sahoo RK, Tuteja N (2014). Biofertilizers function as key player in sustainable agriculture by improving soil fertility, plant tolerance and crop productivity. Microbial Cell Factories 13 (1): 66. - doi: 10.1186/147 5-2859-13-66

Brockerhoff EG, Jactel H, Parrotta JA, Quine CP, Sayer $J$ (2008). Plantation forests and biodiversity: oxymoron or opportunity? Biodiversity and Conservation 17 (5): 925-951. - doi: 10.1007/s105 31-008-9380-x

Brockerhoff EG, Jactel H, Parrotta JA, Ferraz SF (2013). Role of eucalypts and other planted forests in biodiversity conservation and the provision of biodiversity-related ecosystem services. Forest Ecology and Management 1 (301): 43-50. - doi: 10.1016/j.foreco.2012.09.018

Carnus JM, Parrotta J, Brockerhoff E, Arbez M, Jactel H, Kremer A, Lamb D, O'Hara K, Walters $B$ (2006). Planted forests and biodiversity. Journal of Forestry 104 (2): 65-77. - doi: 10.1093/jof/ 104.2.65

Carrara LA, Faria LC, Antas PD, De Matos JR, Sartorio RC, Scopel ET (2010). Commercial Eucalyptus plantation as communal night roosts of parrots Amazona spp.: selective convergence. Revista Brasileira de Ornitología 18 (1): 49-54.

Chen X, Lupi F, He G, Liu J (2009). Linking social norms to efficient conservation investment in payments for ecosystem services. Proceedings of the National Academy of Sciences USA 106 (28): 11812-11817. - doi: 10.1073/pnas.08099801 06

Chinnaraj S, Malimuthu C (2011). Development of micro-propagation and mini cutting protocol for fast growing Melia, Dalbergia and Eucalyptus clones for pulpwood and bio-energy plantations. BMC Proceedings 5 (7): 1-3. - doi: 10.1186/ 1753-6561-5-S7-P131

Corbin J, D'Antonio CM (2004). Effects of exotic species on soil nitrogen cycling: implications for restoration 1. Weed Technology 18 (sp1): 14641467. - doi: 10.1614/0890-037X(2004)018[1464: EOESOS]2.0.CO;2
Dias T, Dukes A, Antunes PM (2015). Accounting for soil biotic effects on soil health and crop productivity in the design of crop rotations. Journal of the Science of Food and Agriculture 95 (3): 447-454. - doi: 10.1002/jsfa.6565

Dong B, Zhao K, Wang Z, Jia Z, Ma L, Xia X (2018). Forest recovery after clear-cutting in Chinese pine (Pinus tabuliformis) plantations of North China. Journal of Arid Land 10 (2): 233248. - doi: 10.1007/s40333-018-0004-3

D'Amato D, Rekola M, Wan M, Cai D, Toppinen A (2017). Effects of industrial plantations on ecosystem services and livelihoods: perspectives of rural communities in China. Land Use Policy 63 (8): 266-278. - doi: 10.1016/j.landusepol.20 17.01.044

Ehrenfeld JG (2003). Effects of exotic plant invasions on soil nutrient cycling processes. Ecosystems 6 (6): 503-23. - doi: 10.1007/s10021-0020151-3

Erskine PD, Lamb D, Bristow M (2006). Tree species diversity and ecosystem function: can tropical multi-species plantations generate greater productivity? Forest Ecology and Management 233 (2-3): 205-210. - doi: 10.1016/j.foreco.2006. 05.013

Evans J (1976). Plantations: productivity and prospects. Australian Forestry 39 (3): 150-163. doi: 10.1080/00049158.1976.10674148

Evans J (2009). Planted forests: uses, impacts, and sustainability. Food and Agriculture Organization of the United Nations, Rome, Italy, pp. 213. [online] URL: http://books.google.com/boo ks?id=FUXXvmChRF4C

FAO (2011). Plantation forestry and water. The Brazilian Forests Dialogue, Rio de Janeiro, Brazil, pp. 24-25.

FAO (2020). State of world's forests, annual rate of forest expansion and deforestation, 19902020. Web site. [online] URL: http://www.fao. org/documents/card/en/c/ca8642en

Farooq TH, Tigabu M, Ma X, Zou X, Liu A, Odén PC, Wu P (2018). Nutrient uptake, allocation and biochemical changes in two Chinese fir cuttings under heterogeneous phosphorus supply. iForest - Biogeosciences and Forestry 11 (3): 411417. - doi: 10.3832/ifor2657-011

Farooq TH, Yan W, Rashid MHU, Tigabu M, Gilani MM, Zou XH, Wu PF (2019a). Chinese fir (Cunninghamia lanceolata) a green gold of China with continues decline in its productivity over the successive rotations: a review. Applied Ecology and Environmental Research 17 (5): 11055-11067. - doi: 10.15666/aeer/1705_11055110 67

Farooq TH, Wu W, Tigabu M, Ma X, He Z, Rashid MHU, Gilani MM, Wu P (2019b). Growth, biomass production and root development of Chinese fir in relation to initial planting density. Forests 10 (3): 236. - doi: 10.3390/f10030236

Farooq TH, Ma X, Rashid MH, Wu W, Xu J, Tarin MW, He Z, Wu P (2019C). Impact of stand density on soil quality in Chinese fir (Cunninghamia lanceolata) monoculture. Applied Ecology and Environmental Research 17 (2): 3553-66. - doi: 10.15666/aeer/1702_35533566

Forrester DI, Bauhus J, Cowie AL, Vanclay JK (2006). Mixed-species plantations of Eucalyptus with nitrogen-fixing trees: a review. Forest Ecology and Management 233(2-3): 211-230. doi: 10.1016/j.foreco.2006.05.012
Fox TR (2000). Sustained productivity in intensively managed forest plantations. Forest Ecology and Management 138(1-3): 187-202. - doi: 10.1016/S0378-1127(00)00396-0

Freer-Smith P, Muys B, Bozzano M, Drössler L, Farrelly N, Jactel H, Korhonen J, Minotta G, Nijnik M, Orazio C (2019). Plantation forests in Europe: challenges and opportunities. From Science to Policy 9, EFI, Joensuu, Finland, pp. 6-30. - doi: 10.36333/fso9

Gerber JF (2011). Conflicts over industrial tree plantations in the South: who, how and why? Global Environmental Change 21 (1): 165-176. doi: 10.1016/j.gloenvcha.2010.09.005

Grossiord C, Granier A, Gessler A, Pollastrini M, Bonal D (2013). The influence of tree species mixture on ecosystem-level carbon accumulation and water use in a mixed boreal plantation. Forest Ecology and Management 298: 8292. - doi: 10.1016/j.foreco.2013.03.001

Hartmann H, Daoust G, Bigué B (2010). Negative or positive effects of plantation and intensive forestry on biodiversity: a matter of scale and perspective. The Forestry Chronicle 86 (3): 35464. - doi: 10.5558/tfc86354-3

Hu YL, Wang SL, Zeng DH (2006). Effects of single Chinese fir and mixed leaf litters on soil chemical, microbial properties and soil enzyme activities. Plant and Soil 282 (1-2): 379-386. - doi: 10.1007/s11104-006-0004-5

Larjavaara M (2008). A review on benefits and disadvantages of tree diversity. Open Forest Science Journal 1 (1): 24-26. - doi: 10.2174/18743 98600801010024

Li Y, Awada T, Zhou X, Shang W, Chen Y, Zuo X, Wang S, Liu X, Feng J (2012). Mongolian pine plantations enhance soil physico-chemical properties and carbon and nitrogen capacities in semi-arid degraded sandy land in China. Applied Soil Ecology 56: 1-9. - doi: 10.1016/j.apsoil. 2012.01.007

Li Y, Hui G, Yu S, Luo Y, Yao X, Ye S (2017). Nearest neighbour relationships in Pinus yunnanensis var. tenuifolia forests along the Nanpan River, China. iForest - Biogeosciences and Forestry 10 (4): 746-753. - doi: 10.3832/ifor2405-010

Li Y, He J, Lu L, Xu J, Wang H, Ye S (2020). The long-term effects of thinning and mixing on species and structural diversity of Chinese fir plantations. New Forests. - doi: 10.1007/s11056020-09794-2

Liao C, Luo Y, Fang C, Chen J, Li B (2012). The effects of plantation practice on soil properties based on the comparison between natural and planted forests: a meta-analysis. Global Ecology and Biogeography 21 (3): 318-27. - doi: 10.1111/j. 1466-8238.2011.00690.x

Lima WD, Laprovitera R, Ferraz SF, Rodrigues CB, Silva MM (2012). Forest plantations and water consumption: a strategy for hydrosolidarity. International Journal of Forestry Research 2012: 1-8. - doi: 10.1155/2012/908465

Lin K, Yu XT, Huang BL, He ZY (2001). Dynamical characteristics of undergrowth plant diversity in Chinese fir plantations. Chinese Journal of Applied and Environmental Biology 7 (1): 13-19. [In Chinese]

Lindenmayer DB, Franklin JF, Fischer J (2006). General management principles and a checklist of strategies to guide forest biodiversity conservation. Biological conservation 131 (3): 433- 
45. - doi: 10.1016/j.biocon.2006.02.019

Liu J, Li S, Ouyang Z, Tam C, Chen X (2008). Ecological and socioeconomic effects of China's policies for ecosystem services. Proceedings of the National Academy of Sciences USA 105 (28): 9477-9482. - doi: 10.1073/pnas.0706436105 Liu CLC, Kuchma O, Krutovsky KV (2018). Mixedspecies versus monocultures in plantation forestry: development, benefits, ecosystem services and perspectives for the future. Global Ecology and Conservation 15: e00419. - doi: 10.1016/j.gecco.2018.eo0419

Lü Y, Fu B, Wei W, Yu X, Sun R (2011). Major ecosystems in China: dynamics and challenges for sustainable management. Environmental Management 48 (1): 13-27. - doi: $10.1007 /$ soo26 7-011-9684-6

Ma X, Liu A, Ma Z, Fan S (2000). A comparative study on nutrient accumulation and distribution of different generations of Chinese fir plantations. The Journal of Applied Ecology 11 (4): 501-506. [online] URL: http://europepmc.org/ article/med/11767665

Ma X, Heal KV, Liu A, Jarvis PG (2007). Nutrient cycling and distribution in different-aged plantations of Chinese fir in southern China. Forest Ecology and Management 243 (1): 61-74. - doi: 10.1016/j.foreco.2007.02.018

Martin PS, Gheler-Costa C, Lopes PC, Rosalino LM, Verdade LM (2012). Terrestrial non-volant small mammals in agro-silvicultural landscapes of Southeastern Brazil. Forest Ecology and Management 282: 185-195. - doi: 10.1016/j.for eco.2012.07.002

Mason WL, Connolly T, Pommerening A, Edwards C (2007). Spatial structure of semi-natural and plantation stands of Scots pine (Pinus sylvestris L.) in northern Scotland. Forestry 80 (5): 567-586. - doi: 10.1093/forestry/cpmo38 Mayoral C, Van Breugel M, Cerezo A, Hall JS (2017). Survival and growth of five neotropical timber species in monocultures and mixtures. Forest Ecology and Management 403: 1-11. - doi: 10.1016/j.foreco.2017.08.002

Miao L, Zhu F, He B, Ferrat M, Liu Q, Cao X, Cui X (2013). Synthesis of China's land use in the past 300 years. Global and Planetery Change 100: 224-233. - doi: 10.1016/j.gloplacha.2012.10.021

Minghe L, Ritchie GA (1999). Eight hundred years of clonal forestry in China: I. Traditional afforestation with Chinese fir (Cunninghamia lanceolata (Lamb.) Hook.). New Forests 8 (1): 131-142. - doi: 10.1023/A:1006558900234

Oliet JA, Jacobs DF (2012). Restoring forests: advances in techniques and theory. New Forests 1 (43): 535-541. - doi: 10.1007/s11056-012-9354-4

Paquette A, Messier C (2010). The role of plantations in managing the world's forests in the Anthropocene. Frontiers in Ecology and the Environment 8 (1): 27-34. - doi: 10.1890/080116

Pereira HM, Navarro LM, Martins IS (2012). Global biodiversity change: the bad, the good, and the unknown. Annual Review of Environment and Resources 37: 25-50. - doi: 10.1146/ annurev-environ-042911-093511

Pirard R, Dal Secco L, Warman R (2016). Do timber plantations contribute to forest conservation? Environmental Science and Policy 57: 122130. - doi: 10.1016/j.envsci.2015.12.010

Ren G, Young SS, Wang L, Wang W, Long Y, Wu R, Li J, Zhu J, Yu DW (2013). Effectiveness of
China's national forest protection program and nature reserves. Conservation Biology 29 (5): 1368-1377. - doi: 10.1111/cobi.12561

Ruiz-Jaen MC, Potvin C (2011). Can we predict carbon stocks in tropical ecosystems from tree diversity? Comparing species and functional diversity in a plantation and a natural forest. New Phytologist 189 (4): 978-987. - doi: 10.1111/j.14 69-8137.2010.03501.x

Rundel PW, Dickie IA, Richardson DM (2014). Tree invasions into treeless areas: mechanisms and ecosystem processes. Biological Invasions 16 (3): 663-675. - doi: 10.1007/s10530-013-0614-9 Sasaki N, Yoshimoto A (2010). Benefits of tropical forest management under the new climate change agreement - A case study in Cambodia. Environmental Science and Policy 13 (5): 384392. - doi: 10.1016/j.envsci.2010.04.007

Scott DF (2005). On the hydrology of industrial timber plantations. Hydrological Processes 19 (20): 4203-6. - doi: 10.1002/hyp.6104

Scullion JJ, Vogt KA, Drahota B, Winkler-Schor S, Lyons M (2019). Conserving the last great forests. a meta-analysis review of the drivers of intact forest loss and the policies and strategies to save them. Frontiers in Forests and Global Change 2: 62. - doi: 10.3389/ffgc.2019.00062

Selvaraj S, Duraisamy V, Huang Z, Guo F, Ma X (2017). Influence of long-term successive rotations and stand age of Chinese fir (Cunninghamia lanceolata) plantations on soil properties. Geoderma 306: 127-134. - doi: 10.1016/j.geoder ma.2017.07.014

SFA (2009). Report of forest resources in China (2004-2008). China Forestry Press, Beijing, China, pp. 68.

SFA (2014). Report of forest resources in China (2009-2013). China Forestry Press, Beijing, China, pp. 86.

SFA (2019). Forest resources in China. National forestry and grassland administration press, Beijing, China, pp. 1-28.

Shi M, Qi J, Yin R (2016). Has China's natural forest protection program protected forests? Heilongjiang's experience. Forests $7(10):$ 218. - doi: 10.3390/f7100218

Stenert C, Bacca RC, Moraes AB, De Avila AC, Maltchik L (2012). Negative effects of exotic pine invasion on macro invertebrate communities in southern Brazil coastal ponds. Marine and Freshwater Research 63 (4): 283-92. - doi: 10.1071/MF11169

Stephens SS, Wagner MR (2007). Forest plantations and biodiversity: a fresh perspective. Journal of Forestry 105 (6): 307-13. - doi: 10.1093 /jof/105.6.307

Tallis H, Kareiva P, Marvier M, Chang A (2008). An ecosystem services framework to support both practical conservation and economic development. Proceedings of the National Academy of Sciences USA 105 (28): 9457-9464. - doi: 10.1073/pnas.0705797105

Trumbore S, Brando P, Hartmann H (2015). Forest health and global change. Science 349 (6250): 814-818. - doi: 10.1126/science.aac6759

Wang Z, Daun C, Yuan L, Rao J, Zhou Z, Li J, Yang C, Xu W (2010). Assessment of the restoration of a degraded semi-humid evergreen broadleaf forest ecosystem by combined single-indicator and comprehensive model method. Ecological Engineering 36 (6): 757-767. - doi: 10.1016/j.ecol eng.2010.01.006

Wang Z, Yang H, Dong B, Zhou M, Ma L, Jia Z, Duan J (2017). Regeneration response to canopy gap size in a Chinese pine plantation: species diversity patterns, size structures and spatial distributions. Forest Ecology and Management 397: 97-107. - doi: 10.1016/j.foreco.2017.04.037

Wendland KJ, Honzák M, Portela R, Vitale B, Rubinoff S, Randrianarisoa J (2010). Targeting and implementing payments for ecosystem services: opportunities for bundling biodiversity conservation with carbon and water services in Madagascar. Ecological Economics 69 (11): 2093-2107. - doi: 10.1016/j.ecolecon.2009.01.002 Whitehead D, Beadle CL (2004). Physiological regulation of productivity and water use in Eucalyptus: a review. Forest Ecology and Management 193 (1-2): 113-140. - doi: 10.1016/j.foreco. 2004.01.026

Widenfalk O, Weslien J (2009). Plant species richness in managed boreal forests effects of stand succession and thinning. Forest Ecology and Management 257 (5): 1386-1394. - doi: 10.1016/j.foreco.2008.12.010

Wu Z, Zhou C, Zhou X, Hu X, Gan J (2018). Variability after 15 years of vegetation recovery in natural secondary forest with timber harvesting at different intensities in southeastern China: community diversity and stability. Forests 9 (1): 40. - doi: 10.3390/f9010040

Wunder S, Engel S, Pagiola S (2008). Taking stock: A comparative analysis of payments for environmental services programs in developed and developing countries. Ecological Economics 65 (4): 834-852. - doi: 10.1016/j.ecolecon. 2008.03.010

Xu J (2011). China's new forests aren't as green as they seem. Nature 477 (7365): 371. - doi: 10.1038/477371a

Xu J, Zhang Z, Liu W, McGowan PJK (2012). A review and assessment of nature reserve policy in China: advances, challenges and opportunities. Oryx 46 (4): 554-562. - doi: 10.1017/So030 605311000810

Yamagawa H, Ito S, Nakao T (2010). Restoration of semi-natural forest after clear-cutting of conifer plantations in Japan. Landscape and Ecological Engineering 6 (1): 109. - doi: 10.1007/s113 55-009-0088-1

Yang Y, He Z, Zou S, Yu X (1998). A study on the soil microbes and biochemistry of rhizospheric and total soil in natural forest and plantation of Castanopsis kauakamii. Acta Ecologica Sinica 18 (2): 198-202. [In Chinese]

Yang X, Jia Z, Ci L (2010). Assessing effects of afforestation projects in China. Nature 466 (7304): 315. - doi: 10.1038/466315C

Yin RS, Xu JT, Li Z, Liu C (2005). China's ecological rehabilitation: the unprecedented efforts and dramatic impacts of reforestation and slope protection in western China. China Environment Series 7 (23): 17-32.

You C, Jiang L, Xi F, Wang W, Li M, Xu Z, Gu L, Wang F, Zhang $Z$ (2015). Comparative evaluation of different types of soil conditioners with respect to their ability to remediate consecutive tobacco monoculture soil. International Journal of Agriculture and Biology 17 (5): 969975. - doi: 10.17957/IJAB/15.0017

Yu D, Zhou L, Zhou W, Ding H, Wang Q, Wang Y, $\mathrm{Wu} X$, Dai $L$ (2011). Forest management in 
Northeast China: history, problems, and challenges. Environmental Management 48 (6): 1122-1135. - doi: 10.1007/s00267-011-9633-4

Zemp DC, Ehbrecht M, Seidel D, Ammer C, Craven D, Erkelenz J, Irawan B, Sundawati L, Hölscher D, Kreft H (2019). Mixed-species tree plantings enhance structural complexity in oil palm plantations. Agriculture, Ecosystems and Environment 1 (283): 106564. - doi: 10.1016/j. agee.2019.06.003

Zeng W, Tomppo E, Healey SP, Gadow KV (2015). The national forest inventory in China: history results - international context. Forest Ecosystem 2 (1): 23. - doi: 10.1186/s40663-015-0047-2

Zhang B, Li W, Xie G (2010). Ecosystem services research in China: progress and perspective. Ecological Economics 69 (7): 1389-1395. - doi: 10.1016/j.ecolecon.2010.03.009
Zhang Y, Chen HY, Reich PB (2012). Forest productivity increases with evenness, species richness and trait variation: a global meta-analysis. Journal of Ecology 100 (3): 742-749. - doi: 10.1111 /j.1365-2745.2011.01944.x

Zhang D, Stenger A, Harou PA (2015). Policy instruments for developing planted forests: Theory and practices in China, the US, Brazil, and France. Journal of Forest Economics 21 (4): 223237. - doi: 10.1016/j.jfe.2015.09.004

Zhang Y, Peng C, Li W, Tian L, Zhu Q, Chen H, Fang X, Zhang G, Liu G, Mu X (2016). Multiple afforestation programs accelerate the greenness in the "Three North" region of China from 1982 to 2013. Ecological Indicators 61 (2): 404412. - doi: 10.1016/j.ecolind.2015.09.041

Zhao T (1988). The change of ecological conditions in Eucalyptus plantation. Forestry Science and Technology of Yunnan Province 88 (4): 22. [In Chinese]

Zhou G, Wei X, Yan J (2002). Impacts of Eucalyptus (Eucalyptus exserta) plantation on sediment yield in Guangdong Province, southern China: a kinetic energy approach. Catena 49 (3): 231-51. doi: 10.1016/S0341-8162(02)00030-9

Zhou L, Shalom A-DD, Wu P, Li S, Jia Y, Ma X (2015). Litterfall production and nutrient return in different-aged Chinese fir (Cunninghamia lanceolata) plantations in South China. Journal of Forestry Research 26 (1): 79-89. - doi: 10.1007 /s11676-014-0011-y

Zhou H, Meng S, Liu Q (2016). Diameter growth, biological rotation age and biomass of Chinese fir in burning and clearing site preparations in subtropical China. Forests 7 (8): 177. - doi: 10.33 90/f7080177 